\title{
50 Percent Cell Culture Infective Dose per Milliliter
}

National Cancer Institute

\section{Source}

National Cancer Institute. 50 Percent Cell Culture Infective Dose per Milliliter. NCI

Thesaurus. Code C120845.

A potency unit equal to the potency at which one milliliter of preparation contains one 50 percent cell culture infective dose. 